\title{
静岡県相良海岸における静穞時の 離岸流発生特性 \\ GENERATION OF RIP CURRENT UNDER CALM SEA CONDITION AT SAGARA COAST, SHIZUOKA, JAPAN
}

\author{
石川仁憲 1 ・岡辺拓巳 2 ・堀口敬洋 3 ・青木伸一 4 \\ Toshinori ISHIKAWA, Takumi OKABE, Takahiro HORIGUCHI and Shin-ichi AOKI

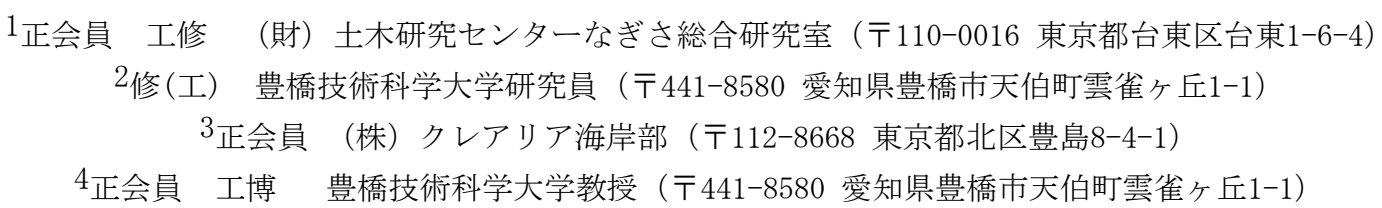

The purpose of this study was to investigate rip current generation under calm sea condition, i.e. good condition for sea bathing. A two-week continuous measurement of near-shore currents was carried out at two stations near the breakwater of a fishery harbor at Sagara coast, Shizuoka. Characteristics of the rip current such as time variation, spectral features and vertical structure were discussed based on the data. Generation mechanism of the rip current was also discussed associated with wave properties and wind conditions. Sudden velocity increase up to $0.2 \mathrm{~m} / \mathrm{s}$ was observed for 1 - 2 hours under very calm condition, which does not show very clear relationship with wave and wind conditions.

Key Words : Rip current, Field measurement, Calm sea condition, Water safety, Sagara Coast

\section{1.はじめに}

海浜における溺水事故は後を絶たない。 小峯ら 11 によれば，ライフセーバーが活動する 200 箇所の海 水浴場では毎年約 2,000 件のレスキューが行われ， 救出段階で意識が無い重溺者のうち蘇生し社会復帰 した人の割合は 49\%であり，迅速な救助よりも事故 を起こさないための予防策が重要である。一方，海 水浴場では, 波高が高い場合は海岸管理者, ライフ セーバーの判断により，遊泳注意，遊泳禁止の措置
がとられるため，溺水事故は相対的に起こりにくく， むしろ静穏時における離岸流による事故が多い1). この主因である離岸流について，これまでに観測や 数值モデル等で現象解明が試みられているものの, 利用者の多い静榣時に着目した例は少ない。そこで 本研究は, 溺水事故防止の観点から静稻時の離岸流 発生メカニズムを明らかにすることを目的に，静岡 県相良海岸を対象に，現地観測に加え，ライフセー バーやサーファーの知見をふまえ，同海岸における 静穏時離岸流の発生特性を分析した。

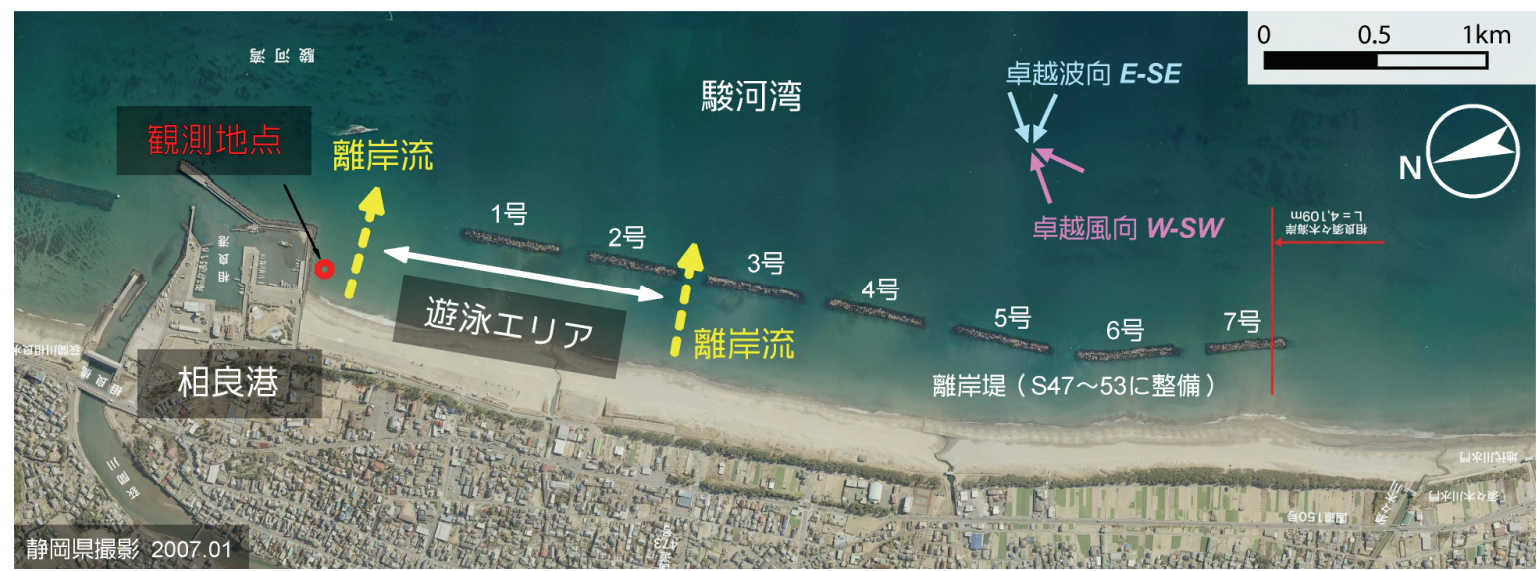

図-1 対象海岸の概要と観測地点 
表-1 波高・流速の観測概要

\begin{tabular}{|c|c|c|c|c|c|c|}
\hline 観測項目 & 計測機器 & 観測期間 & 観測仕様 & $\begin{array}{l}\text { 海底〜 } \\
\text { センサー }\end{array}$ & 水深 & 備考 \\
\hline 波高 & $\begin{array}{c}\text { アイオーテクニック製 } \\
\text { HJ-401（水圧式波高計） }\end{array}$ & \multirow{3}{*}{$\begin{array}{c}2010 \text { 年 } 9 \text { 月 } 7 \text { 日 } \\
12: 00: 00 \\
\sim \\
2010 \text { 年 } 9 \text { 月 } 23 \text { 日 } \\
08: 00: 00\end{array}$} & $\begin{array}{c}2 \mathrm{~Hz} \\
\text { 連続観測 }\end{array}$ & $0.43 \mathrm{~m}$ & \multirow{3}{*}{$\begin{array}{c}\text { 平均水深 } \\
3.3 \mathrm{~m}\end{array}$} & $\begin{array}{l}\text { 観測水圧を } \\
\text { 水位として処理 }\end{array}$ \\
\hline $\begin{array}{l}2 \text { 次元 } \\
\text { 水平流速 }\end{array}$ & $\begin{array}{c}\text { JFE アドバンテック製 } \\
\text { Infinity-EM（電磁流速計） }\end{array}$ & & \begin{tabular}{|c|}
$2 \mathrm{~Hz}$ \\
5 分毎に \\
64 データ
\end{tabular} & $0.7 \mathrm{~m}$ & & - \\
\hline $\begin{array}{c}\text { 流速 } \\
\text { 鈆直分布 }\end{array}$ & $\begin{array}{c}\text { Nortek 製 } \\
\text { Aquadopp 2MHz } \\
\text { （超音波流速プロファイラ） }\end{array}$ & & $\begin{array}{c}5 \text { 分毎に } \\
1 \text { 分間の } \\
\text { 平均值 }\end{array}$ & $\begin{array}{c}0.7 \mathrm{~m} \\
(1 \text { 層目) }\end{array}$ & & 層厚 $0.5 \mathrm{~m} \times 8$ 層 \\
\hline
\end{tabular}

\section{2. 現地調査の概要}

青木ら ${ }^{2)}$ は相良海岸において離岸流観測を行い, 比較的静穏時でも相良港防波堤に沿って速い離岸流 が発生することを明らかにした。しかし観測期間が 3 時間と短く, その発生特性を分析するまでには 至っていない. 本研究では観測期間を2週間, 2地点 で行うことでより多くのデータを取得した。

\section{（1）観測地点および方法}

図-1に示寸対象海岸の中で，離岸流事故が多い相 良港防波堤南側において，2010年9月の約2週間，波 と流れを観測した。観測項目と機器, 設定等の詳細 を表-1に, 計測機器の位置を図-2に示寸。計測機器 は離岸流の空間的な分布を計測するため，沿岸方向 に $10 \mathrm{~m}$ 距離をあけた2つの計測点（P1およびP2）を 設けた。波高計で計測された水圧データは，水深が 浅いことから水圧伝達関数を用いず，そのまま水位 として処理を行なった。

\section{（2）観測期間中の気象条件}

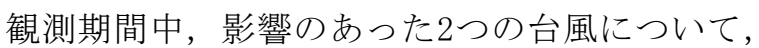
気象庁によるべストトラッグ)を図-3に示す。山陰 沖から関東沖一通過した台風1009号は対象地域の近 くを通過している。また先島諸島を西に進んだ強い 台風1011号は，遠いながらも太平洋沿岸にうねり性 の波をもたらした。

\section{3. 現地調査の結果}

\section{（1）波と流れの特性}

図-4はP1において取得した水位，有義波高 $H_{1 / 3}$, 有義波周期 $T_{1 / 3}$ および底層での 1 時間移動平均流速の 経時変化を示す．観測期間中には2つの台風が発生 したが，台風1009号発生時の波高は $H_{1 / 3}=0.4 \mathrm{~m}$ 以下と 小さく, 台風1011号の場合は, $T_{1 / 3}=14 \mathrm{~s}$ 程度のうね り性の波であるが，波高は大きくても $H_{1 / 3}=0.6 \mathrm{~m}$ 程度 と比較的小さかった。 また静穏時の波浪は $H_{1 / 3}=0.3 \mathrm{~m}$, $T_{1 / 3}=8 \mathrm{~s}$ 前後, 期間中の平均水深は $3.3 \mathrm{~m}$ であった。 一 方，図-1に示すように相良港防波堤の法線は東西方

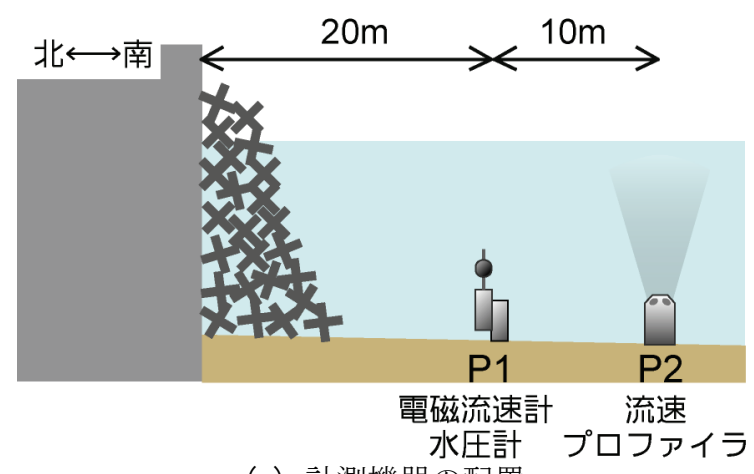

（a）計測機器の配置

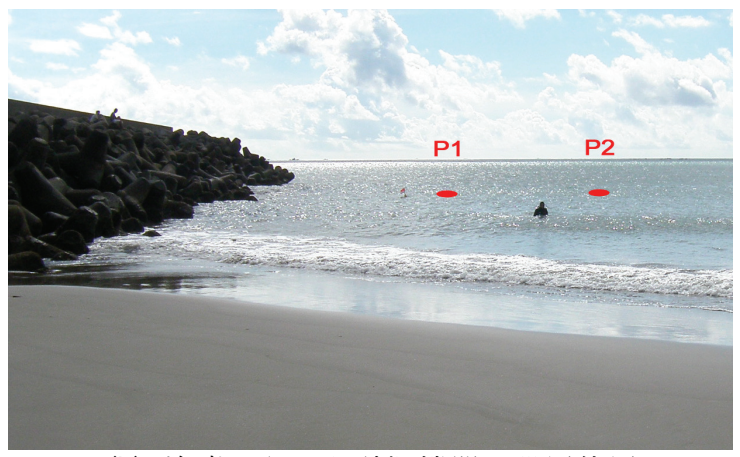

（b）海岸から見た計測機器の設置位置

図-2 観測機器の配置

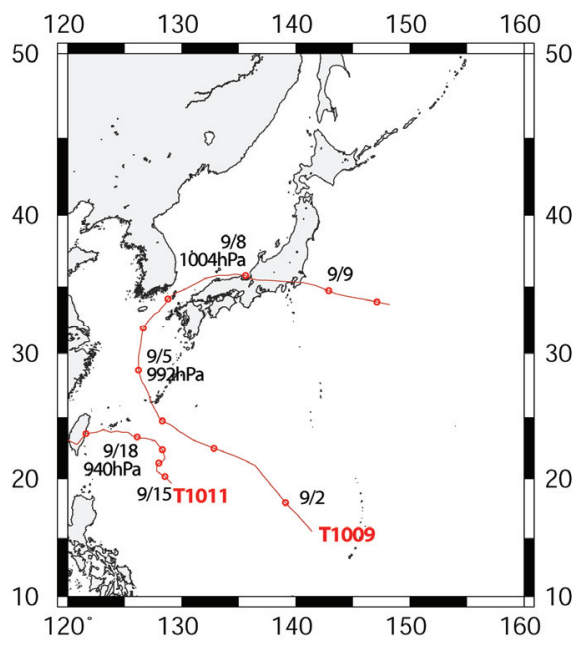

図-3 観測期間中における台風の経路 ${ }^{3)}$ 


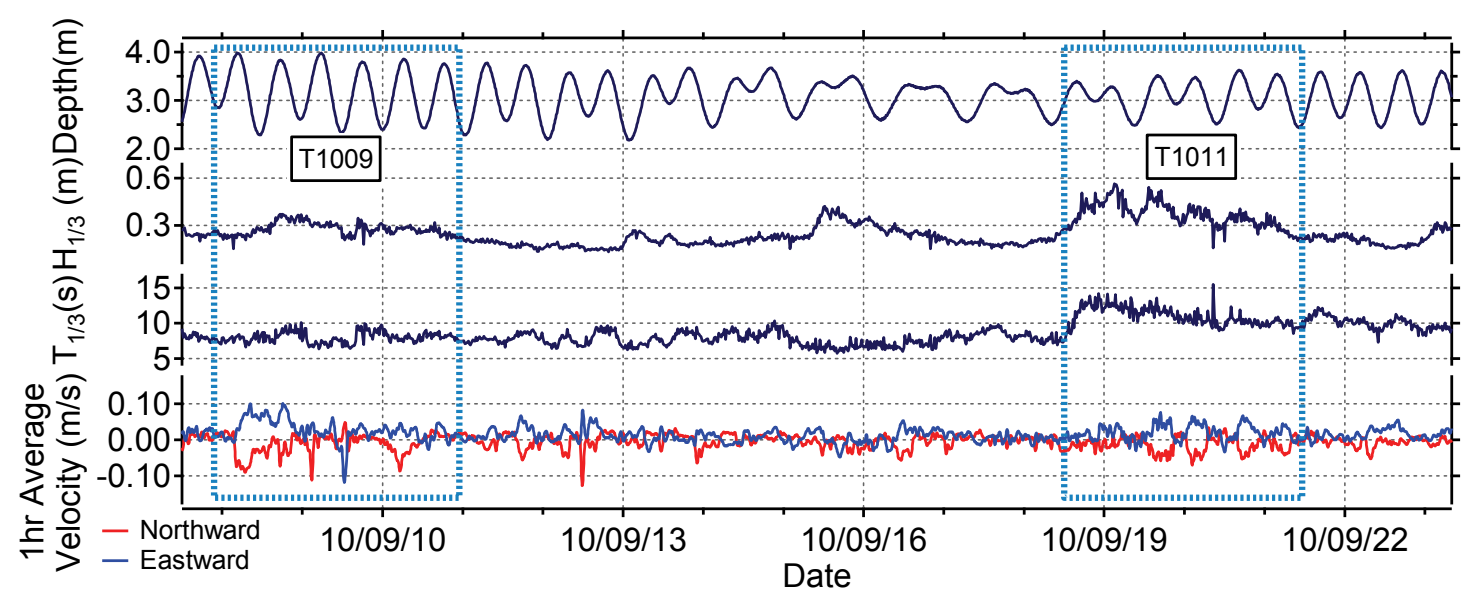

図-4 水位，有義波高，有義波周期および底層の1時間移動平均流速の経時変化 (P1)

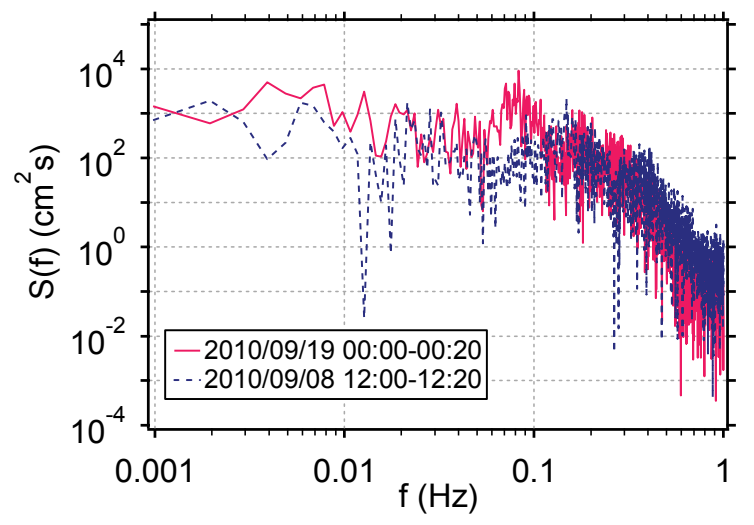

図-5 水位変動のパワースペクトル

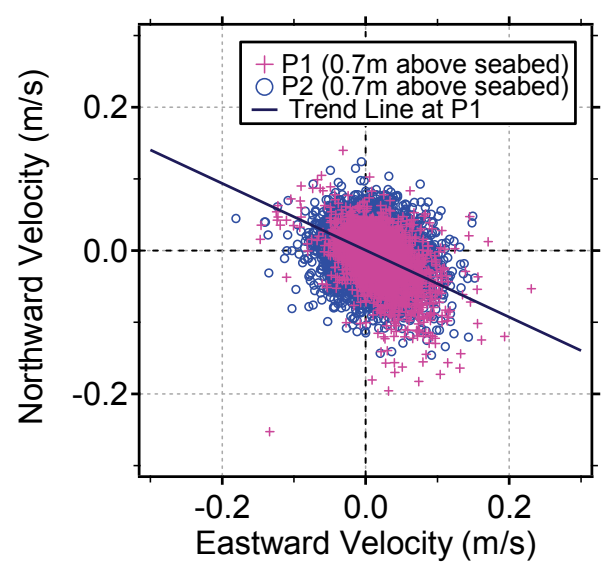

図-6 平均流速の位相面プロット

向に延びており，防波堤と離岸堤の開口部が東南東 方向に開いていることから, Northwardの流速がマ イナス，Eastwardがプラスの場合に沖向き方向の流 れが発生していることになる。図-4より台風発生時 には比較的速い流れが発生しているが，波高が小さ く, 周期が短い台風1009発生時（9月8日）の方が速 い流れが長時間継続して発生していることが分かる。 また，静穏であった9月12日，16日前後においても，

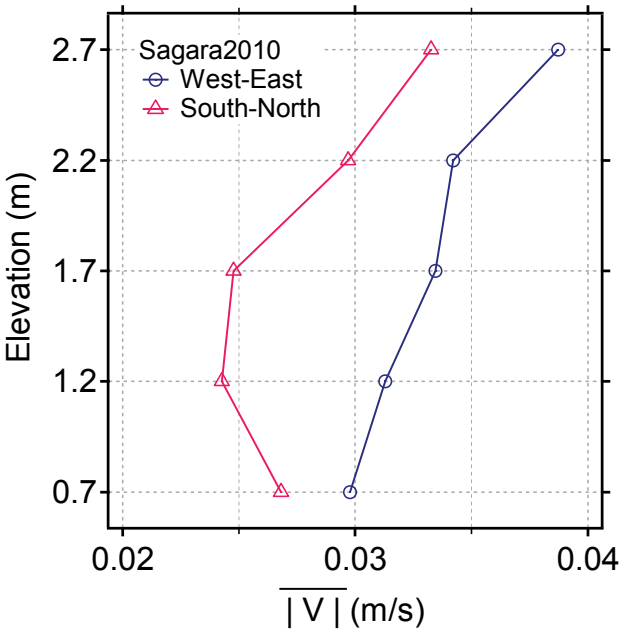

図-7 P2における流速（絶対值）の平均值の鉛直分布

同程度の流速が観測されている。このことから対象 海岸においては，波高，周期の大きさに関係なく， 比較的静穏な条件であっても速い流れが発生してい ることが分かった。

図-5は台風発生時におけるP 1 の 20 分間の水位変動 のパワースペクトルを示す. 比較的長周期の波が来 襲した台風1011号の場合は，周期 $14 \mathrm{~s}(F=0.07 \mathrm{~Hz}) に$ ピークが見られ, 長周期の変動成分もエネルギーも 大きい．なおスペクトル形状がフラットになってい るのは，計測位置が砕波帯内にあるためであると考 えられる

図-6は2つの観測地点における底層での平均流速 の位相面プロットを示す. P1は30秒，P2は1分間の 平均值である。2地点は同程度の流速であり，防波 堤に近い観測点P1では図中のトレンド（実線）が示 すように，防波堤に沿った岸沖（東南東）方向が主 な流軸であり，対象海岸で行われた既往の観測結果 2)とも一致する.

図-7はP2における流速の絶対值を平均した值につ いて，2方向成分の鉛直分布を示したものである. これより, 海底から $2.7 \mathrm{~m}$ 上の表層流速は，底層の值 


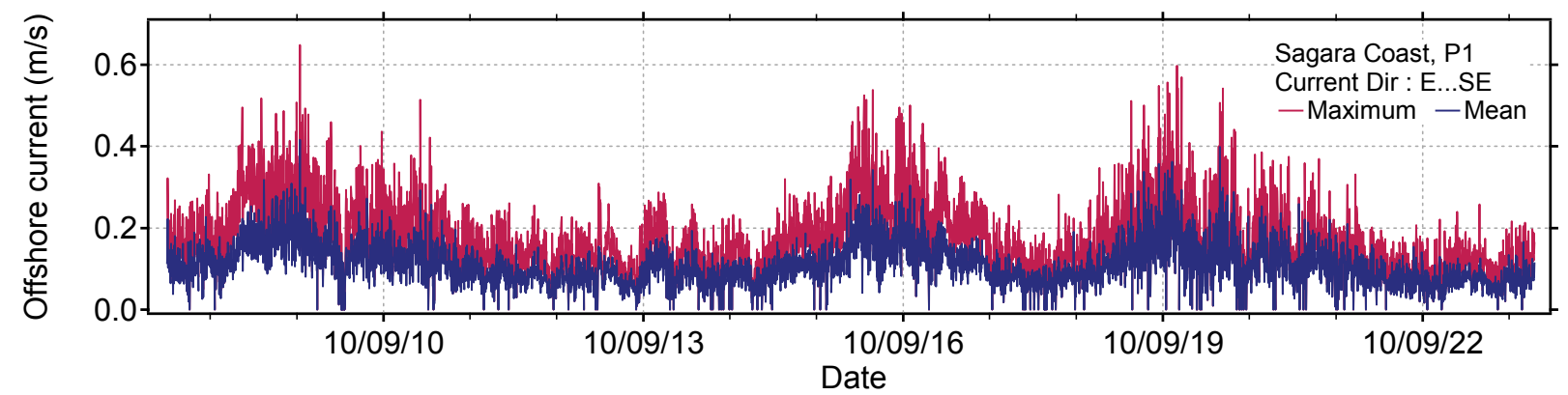

図-8 底層における沖向き流速の最大值および平均值の経時変化 $(\mathrm{P} 1)$

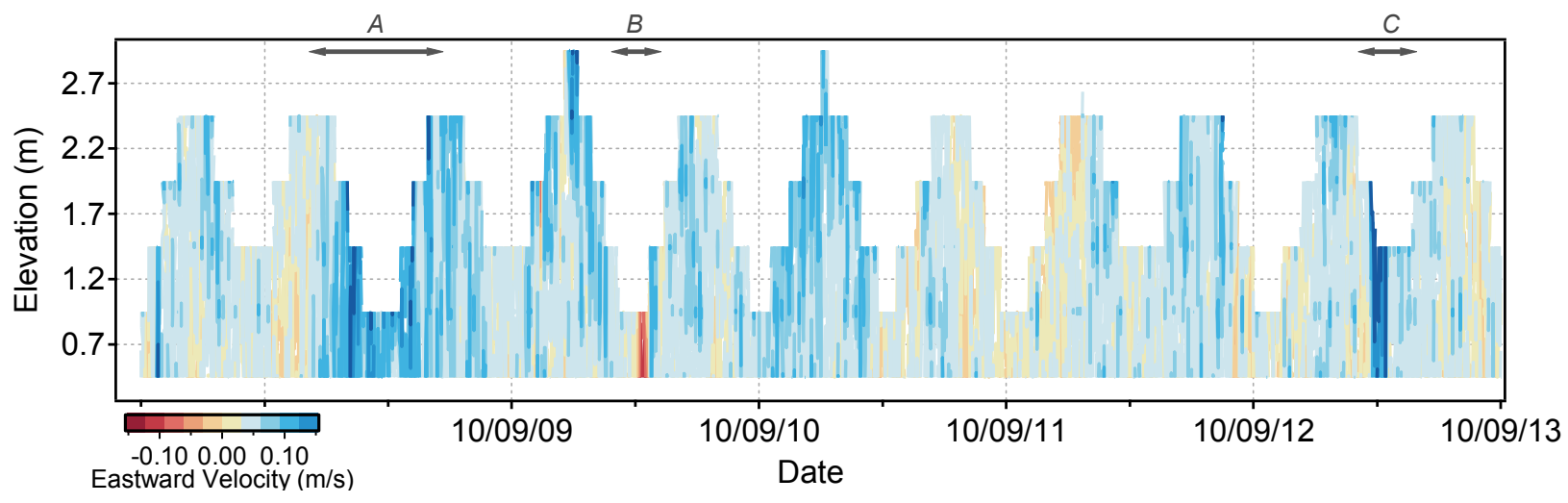

図-9 P2における東方流速の鉛直分布の経時変化

のおよそ1.3倍程度になっており，全層において東 西成分が南北成分より強いことがわかる.

\section{(2) 離岸流の発生特性}

図-8は，P1における5分毎の観測データのうち離 岸流に相当する沖向き（東〜南東方向）の流向デー タを抽出し，最大值と平均值の経時変化を示したも のである。図-4に示した底層での1時間移動平均流 速の経時変化に対応して，台風1009号，台風1011号 発生時および9月16日前後の静穏時に速い離岸流が 発生していることが分かる。これらの期間の最大流 速は0. 5〜0. $6 \mathrm{~m} / \mathrm{s}$ ，平均流速は0.2〜0. $3 \mathrm{~m} / \mathrm{s}$ であった。 $0.2 \mathrm{~m} / \mathrm{s}$ 程度の離岸流に逆らって泳ぐことは困難との 研究報告 ${ }^{2)}$ もり，観測期間中は事故の起きやすい 条件が高頻度に発生していたと考えられる。一方, 波高, 周期の大きさに関係なく，速い離岸流が発生 することが当海岸の特徴である。

図-9は，比較的静穏時に速い離岸流が長時間観測 された台風1009号発生時を含む5日間のP2における 東向きの流速の鉛直分布の経時変化を示す．正の值 （東向き）がおおよその離岸方向を指している. 図 中Aで示す期間では東向きの流れが比較的大きく, 12 時間程度と長く続いている。同様にBおよびCで示 す時間帯は急な流速の増大が見られ，0.2m/s程度の 流れが 1 ～時間継続した後に減少するなど，様々な 時間スケールでの流況の変化が見られた。また，流 向については，水深方向にほぼ一様である.

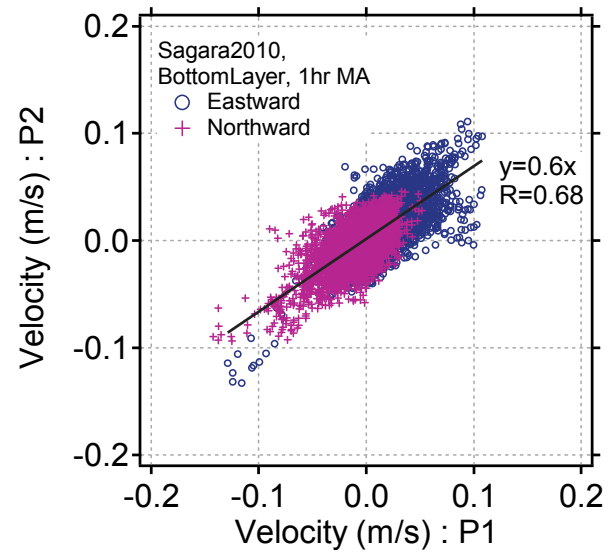

図-10 2つの観測点での底層流速の比較

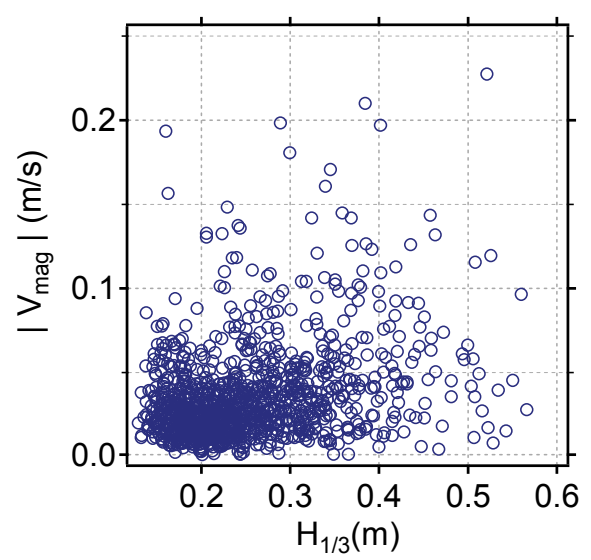

図-11 有義波高と合成流速の絶対值との関係 


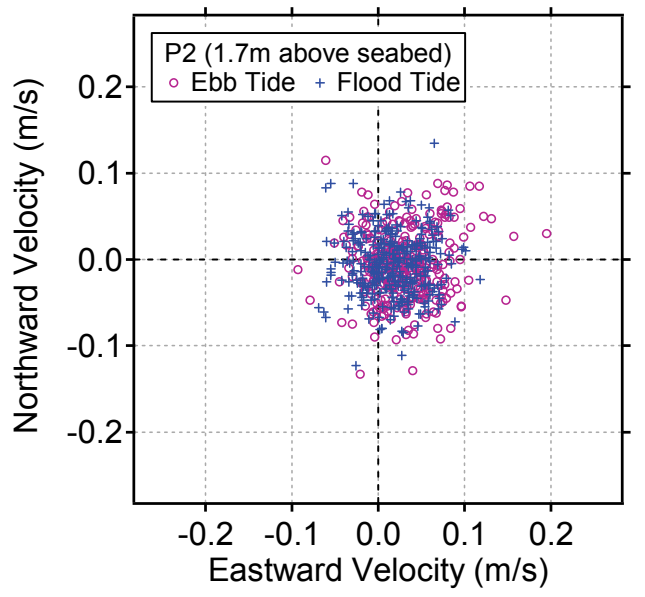

図-12 満潮・干潮前後30分間の流速の位相面プロット

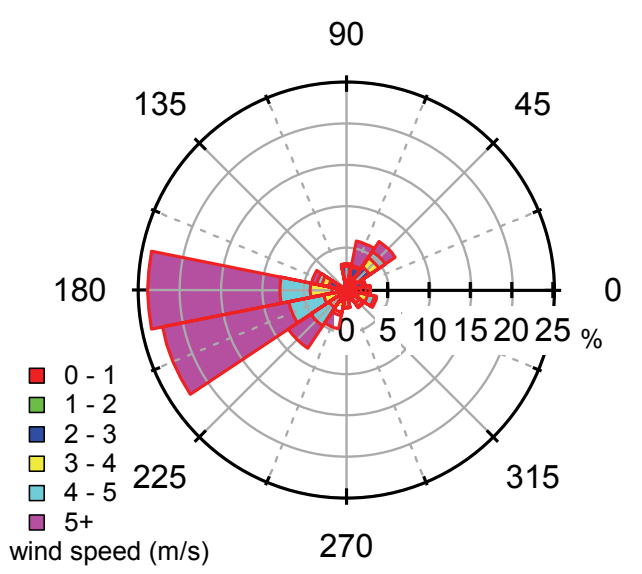

図-13 観測期間中の風配図

図-10は2つの観測点における1時間移動平均した 底層流速の関係について, 東西と南北成分に分けて 示したものである. 両者とも相関係数は $R=0.68$ で,

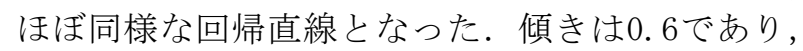
堤防に沿ったP1での流速の方が大きいが，2点での 計測仕様が若干異なることも一因であると考えられ る. また, 両地点の流速の時間変動について, 相互 相関解析による位相は0sであった。これより，2つ の観測点では同じ流向の流れが同期的に変動してい ることが分かる. 図-6の結果もふまえ, 対象海岸で は, 防波堤に沿って幅 $10 \mathrm{~m}$ 以上の離岸流が発生して いることが分かった。

図-11はP1における東西および南北成分を合成し て求めた 30 秒間の底層平均流速の絶対值と, 有義波 高の関係を示したものである。これより，両者の相 関は $R=0.30$ と低く, 波浪と流速の増大は必ずしも対 応しないことがわかった。

一方, 対象海岸で活動するサーファーやライフ セーバーからは満潮時に離岸流の増大が指摘されて いる2). 図-4に示すように，例えば台風1011号発生 時など満潮時において流速の発達が確認できる。し かし, 図-12に示すP2での満潮・干潮前後 30 分間 の流速分布より, 全観測期間における満潮と干潮時

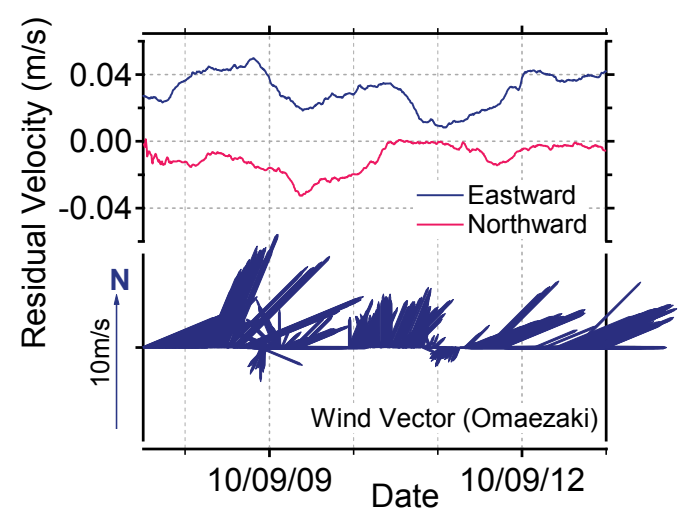

図-14 P2での表層の残差流および御前崎での風速・ 風向の経時変化

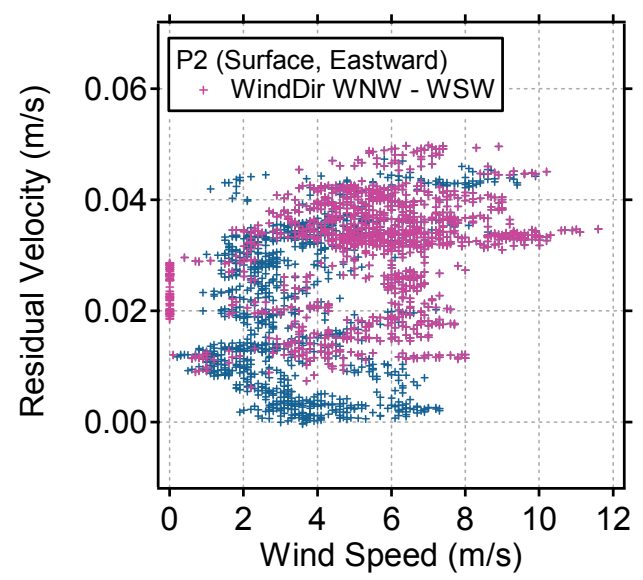

図-15 風速と東西残差流速の関係

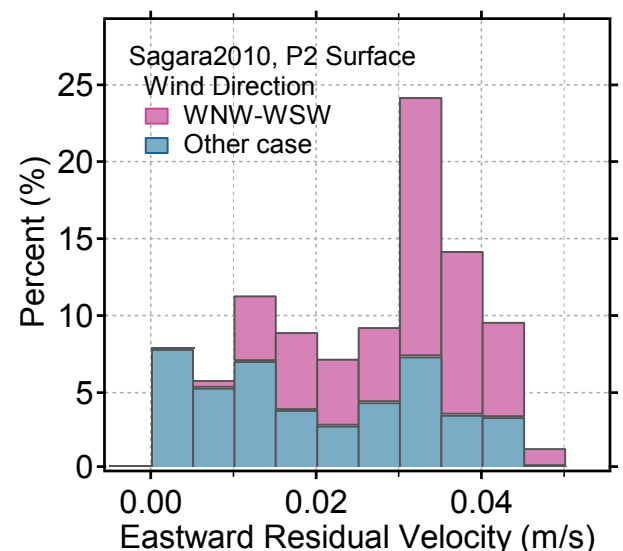

図-16 東西残差流速の頻度分布における風向の割合

の流速には明確な違いは見られなかった.

\section{4. 海岸利用者の意見と静穏時における離岸 流の発生要因の分析}

現地調査結果より, 対象海岸では波高が小さく比 較的静穏な条件であっても, 防波堤に沿って幅 $10 \mathrm{~m}$ 以上の速い離岸流が発生することが分かった. 調查 
結果を基に, 対象海岸で活動するサーファーやライ フセーバーと意見交換を行った結果，静稳時に離岸 流が観測されたことに対して，「防波堤付近では強 い西風発生時に沖へ流される遊泳客が多い.」とい う経験的な意見がでた。そこで風と離岸流の関係を 調べた。図-13は相良海岸の南 $10 \mathrm{~km}$ に位置する御前 崎特別地域気象観測所で観測された調査期間中の 10 分平均值による風配図を示す。西，西南西からの $5 \mathrm{~m}$ 以上の風が多くを占めている.

図-14は，比較的静穏時に速い離岸流が観測され た期間におけるP2の表層流速を25時間移動平均した 残差流成分と, 10分間平均風速および風向の経時変 化を示す. 西よりの風が強まると, 東向きの残差流 速が大きくなり, 風速の増大と離岸流の発生が対応 していることが分かる。

図-15はP2における表層の残差流速（東西成分） と風速の関係を示したものである。西寄りの風（西 北西〜西南西）が吹いた場合の流速は赤色で示す.

図より，残差流の東西成分は観測期間を通して東向 き（正）であることが分かる。風速と流速の関係は 明確ではないが，風速 $8 \mathrm{~m} / \mathrm{s}$ 以上では残差流が大きく， また，西寄りの風が吹いた場合に残差流が大きいこ とが分かる。

図-16はP2における表層の東西残差流速の頻度分 布について，西寄り（西北西〜西南西）とそれ以外 の風向の割合を示したものである. 東向きの流速が 速くなるに従って, 西寄りの風の発生頻度が多くな る傾向にあり，西風の表層東向き流れへの寄与が高 いことが分かる.

\section{5. 考察}

観測データを分析した結果，相良海岸では，波高 が小さく比較的静穏な条件であっても，防波堤に 沿って幅 $10 \mathrm{~m}$ 以上速い離岸流が突発的発生するこ とが分かった。これは対象海岸において防波堤近く で離岸流事故が多いことを裏付ける結果である。ま た静穏時の離岸流の発生要因として, 卓越する西寄 りの風による影響が大きいことが分かった。相良海 岸は東向きに面した卓越風向の風下側に開けた海岸 で，さらに相良港防波堤の法線が東西方向に延びる 条件のため, 卓越する西寄りの風により, 防波堤隣 接部において定常的に離岸流が発生しやすいと考え られる。この場合, 遊泳者は離岸流だけでなく, 身 体の水上部分が風の影響を受け，特にフロート（浮 き輪）利用者はより沖向きに流されやすい。このよ うなことからも対象海岸では安全な海浜利用に風況 が強く関係するといえる。このように静稳時の離岸 流の発生には, 波浪条件以外に, 風と地形的な条件 が強く関係すると考えられる。なお, 観測結果から
離岸流と潮汐に明確な関係はみられなかった。

\section{6. おわりに}

本研究では約 2 週間の現地観測とサーファーやラ イフセーバーの知見をふまえ, 同海岸における静稳 時の離岸流の発生特性を検討した。この結果, 比較 的静穏な状況でも防波堤に沿った離岸流の発生が確 認され，その要因として西寄りの風による影響が大 きいと考えられた。一般にライフセーバーは気圧配 置をみればどの時間帯にどの方向から風が強く吹く かを推測できるので，例えば予め危険な時間帯を想 定したパトロール体制を設定することができる。こ のように本研究で得られた知見は, 静稳時における 水難事故防止に活用できると考えられる。一方で, 潮汐による水深増加に伴って離岸流を強く体感した との報告 ${ }^{2)}$, 他の海岸では干潮時に流速の増大を

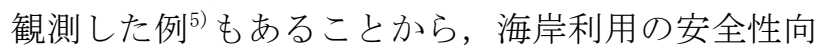
上のためには，潮位変動と離岸流の増幅関係を明ら かにすることが今後の課題である.

謝辞：本調査は土木学会海岸工学委員会・沿岸域研 究連携推進小委員会の活動の一環として行ったもの である。現地調査では，相良サーフライフセービン グクラブの副代表名取芳和氏をはじめライフセー バーの方々, 地元サーファーの方々と, 海岸の安全 利用などについて意見交換を行った。ここに謝意を 表します。

\section{参考文献}

1) 小峯 力, 石川仁憲, 風間隆宏, 堀口敬洋: 海浜にお ける水難事故の発生要因と予防策, 海洋開発論文集, 第 25 巻, pp. 1335-1340, 2009.

2) 青木伸一, 上野成三, 西隆一郎, 小峯 力, 石川仁 憲, 堀口敬洋 : 海岸の安全利用からみた静稳時離岸流 の現地調査一研究者, 実務者と海岸利用者との連携の 試み一, 海洋開発論文集, 第 24 巻, pp. 255-260, 2008.

3)気 象 庁 RSMC Tokyo - Typhoon Center , http://www. jma. go. jp/jma/en/NMHS/indexe_nmhs. htm 1

4) 鈴木康正, 河合弘泰, 望月徳雄 : 砕波帯におけるスペ クトル尖鋭度と波群特性の関係に関する現地観測, 海 岸工学論文集, 第 41 巻, pp. 171-175, 1994.

5) 西 隆一郎, 山口 博, 岩淵 洋, 木村信介, 村井弥 亮, 徳永企世志, 古賀幸夫 : 宮崎県青島海岸での離岸 流観測一水難事故予防のために一, 海岸工学論文集, 第 51 巻, pp. 151-155, 2004. 